\title{
UPAYA HUKUM INDONESIA MENGAJUKAN LANDAS KONTINEN EKSTENSI (antara Peluang dan Tantangan)
}

\author{
Popi Tuhulele \\ Fakultas Hukum Universitas Pattimura Ambon \\ e-mail:popituhulele@yahoo.com
}

\begin{abstract}
ABSTRAK
UNCLOS 1982 menyatakan bahwa suatu negara pantai berhak mengklaim landas kontinen lebih dari 200 mil laut dan tidak boleh lebih dari 350 mil laut (landas kontinen ekstensi).Untuk itu negara pantai harus melakukan delineasi batas terluar LKE ini dan mengajukannya kepada Komisi Batas Landas Kontinen (Commission on the Limits of Continental Shelf, CLCS) melalui Sekretaris Jendral Perserikatan Bangsa-Bangsa (PBB). Indonesia merupakan negara pantai yang memiliki potensi untuk mengajukan Landas Kontinen Ekstensi (LKE). Kajian pendahuluan yang dilakukan beberapa pihak menunjukkan adanya kemungkinan Indonesia dapat mengajukan LKE untuk beberapa wilayah maritim. Dalam hal ini yang di analisis, status terkini dan tantangan yang dihadapi oleh Indonesia dalam proses delineasi batas terluar landas kontinen ekstensi dan pengajuan kepada CLCS.
\end{abstract}

Kata kunci: UNCLOS 1982, Indonesia, penetapan landas kontinen ekstensi.

\begin{abstract}
UNCLOS 1982 stated that a continental has the right to claim basis continent more than 200 miles from sea and not more than 350 miles from sea (LKE). For that case, continent should make the delineation the outborder of this LKE and propose to the (Commission on the Limits of Continental Shelf, CLCS) through The Secretarial General of United Nations). Indonesia is continental which has potential to propose LKE. The primary study done by some parties showed that there is possibility for Indonesia proposes LKE to have some maritime areas. In that case, it is analized the current status and the obstacle of Indonesia in facing the process of delineation the out border of LKE and proposal to CLCS.
\end{abstract}

Keywords: UNCLOS 1982, Indonesia, stipulation of basis continent extention.

\section{PENDAHULUAN}

Kedaulatan merupakan suatu prinsip dasar bagi terciptanya hubungan internasional yang damai. Kedaulatan negara atas wilayah terdiri atas kedaulatan wilayah darat, udara dan laut. Yang dimaksud dengan kedaulatan atas wilayah laut adalah kewenangan yang dimiliki suatu negara di laut guna melaksanakan kewenangannya. Tindakan sepihak negara-negara yang bertalian dengan laut di abad pertengahan dapat digolongkan dalam tindakan-tindakan pengunaan laut sebagai tindakan yang dilakukan untuk melindungi laut sebagai sumber kekayaan, serta tindakan yang menganggap laut sebagai jalur proteksi, baik itu bertujuan untuk melindungi kepentingan keamanan dan pertahanan, bea cukai, kesehatan, penelitian dan lainlain serta tindakan yang bertujuan untuk melindungi laut sebagai sarana komunikasi baik antar pulau ataupun antar negara.
Wilayah daratan dan udara dimiliki oleh semua negara, karena merupakan bagian mutlak bagi kehidupan negara dan penduduknya, sebaliknya wilayah laut hanya dimiliki oleh negara pantai (coastal states) yakni negara yang dihadapannya terdapat kawasan laut. Wilayah laut secara hukum didefinisikan sebagai keseluruhan air laut yang berhubungan secara bebas di seluruh permukaan bumi. Wilayah laut ini mencakup permukaan air, kolam air, dasar laut dan tanah di bawah dasar laut.

Dalam hukum internasional selalu mengupayakan penetapan batas laut yang berlaku secara universal dengan memberikan catatan bagi negara-negara pantai dan pelintas. Semula batas laut teritorial ditentukan berdasarkan kebiasaan yang berlaku dalam praktek ketatanegaraan negara yang bersangkutan dengan memperhatikan kepentingan negara lain sebagai pengguna atau pelintas. 
Dalam konsepsi hukum laut internasional dikenal beberapa konsepsi mengenai kepemilikan dan penggunaan wilayah laut sebagai berikut: a. Res nullius, menyatakan bahwa laut itu tidak ada yang memilikinya; b. Res Communis, menyatakan bahwa laut milik bersama masyarakat dunia, karena itu tidak dapat dimiliki oleh masing-masing negara; c. Mare Liberum, menyatakan bahwa wilayah laut adalah bebas; d. Mare Clausum (the rigt and dominion of the sea) menyatakan bahwa hanya laut sepanjang pantai saja yang dapat dimiliki oleh suatu negara sejauh yang dapat dikuasai dari darat ( \pm 3 mil laut); e. Archipelagic state principles (asas negara kepulauan) yang menjadikan dasar dalam konvensi PBB tentang hukum laut.

Menurut Konvensi Hukum Laut PBB 1982 (UNCLOS 1982), laut dibagi secara horizontal dan vertical. Secara horizontal laut dapat dibagi menjadi: a. Perairan pedalaman, yakni perairan yang berada di sisi dalam garis pangkal; b. Laut teritorial yakni jalur laut yang ada di sisi luar atau di sisi laut garis pangkal selebar tidak lebih dari 12 mil laut; c. Zone tambahan yaitu jalur laut yang merupakan kelanjutan dari laut teritorial yang lebarnya tidak melebihi jarak 24 mil laut dari garis pangkal yang bersangkutan; d. Zone ekonomi eksklusif yaitu jalur laut yang terletak di luar dan berdekatan dengan laut teritorial selebar 200 mil laut dari garis pangkal laut teritorial; e. Laut lepas yaitu bagian laut yang tidak termasuk dalam zone ekonomi Eksklusif, laut teritorial atau perairan pedalaman.

Sedangkan laut secara vertikal dibagi menjadi; a. Ruang udara yang ada di atas laut; b. Kolom air laut (water coloumn); c. Dasar laut (sea bed), Tanah di bawah dasar laut (subsoil) Dasar laut dan tanah dibawahnya dibagi lagi secara horizontal menjadi: 1. Dasar laut dan tanah dibawahnya dari bagian laut secara horizontal; 2. Landas Kontinen, yakni dasar laut dan tanah di bawahnya sampai kejauhan batas landas kontinennya (continental margin) atau sejauh 200 mil laut atau 350 mil laut dari garis pangkal laut teritorial; 3. Area kawasan yakni laut dan dasar samudera dalam tanah dibawahnya yang ada di luar batas juridiksi nasional.

Pembagian laut secara horizontal dan vertikal tersebut di atas memberikan hak-hak yang berbedabeda kepada pemilik kedaulatan laut tersebut dan hubungannya dengan negara lain.

Keadaan ini berubah sesudah Perang Dunia ke II. Faktor penyebab perubahan, yaitu bertambah bergantungnya masyarakat bangsa-bangsa pada laut sebagai sumber kekayaan alam baik hayati maupun nonhayati seperti mineral minyak dan gas bumi, serta kemungkinan pengambilan yang didukung dengan kemajuan teknologi di bidang kelautan. Alasan demikian itu telah mendorong terjadinya tindakan sepihak dari negara-negara untuk melindungi, memelihara dan mencadangkan sumber kekayaan alamnya tidak saja di laut teritorialnya, tetapi juga menghendaki hak berdaulat yang lebih luas lagi, yaitu di laut lepas yang berada diluar yurisdiksinya dan berbatasan dengan laut teritorialnya. Tindakan sepihak negaranegara ini mengakibatkan perubahan dalam ketentuan hukum laut yang terbentuk sebelum perang dan merupakan peristiwa yang mempunyai pengaruh yang jauh dan mendalam serta merupakan kejadian yang cukup penting dalam sejarah perkembangan hukum laut internasional.

Tindakan sepihak negara pertama kali dilakukan oleh pemerintah Amerika Serikat yang menuntut hak atas landas kontinennya, yang dinyatakan dalam Proklamasi Truman 1945 tentang "Continental Shelf" dan Perikanan. Tindakan sepihak Amerika Serikat (USA) dalam perluasan yurisdiksi atas laut lepas yang berbatasan dengan pantai USA untuk tujuan pemanfaatan kekayaan alamnya.

Dalam konferensi hukum laut 1958 di Jenewa, landas kontinen menjadi salah satu pokok pembahasan, konvensi berhasil mencapai kata sepakat dan lahirlah konvensi tentang landas kontinen. Landas kontinen (continental shelf) semula berasal dari istilah geologi yang kemudian masuk ke dalam perbendaharaan istilah hukum.

Landas kontinen biasanya tidak terlalu dalam, sehingga sumber daya alam dari landas kontinen dapat dimanfaatkan dengan teknologi yang ada. Dasar laut di banyak tempat dipisahkan dari tanah di pantai oleh lereng kontinen yang menurut istilah geologis merupakan bagian dari kontinen itu sendiri. Lereng kontinen luasnya berkisar beberapa ratus kilometer persegi dan mempunyai kedalaman sekitar 50 hingga 550 meter. Lereng kontinen di beberapa tempat menyimpan deposit minyak dan gas bumi serta sebagai sumber daya alam hayati. Dalam perkembangannya kemudian menjadi permasalahan baru dalam bidang hukum laut. Permasalahan tersebut timbul karena tidak adanya batasan yang jelas mengenai landas kontinen itu sendiri, sehingga banyak negara lain yang menuntut landas kontinen seluas-luasnya tanpa memperdulikan kepentingan negara tetangganya. Klaim tumpang-tindih dari dua atau lebih negara pada dasarnya bukanlah suatu hal istimewa. Hal ini biasa terjadi di wilayah laut yang berdampingan atau bertetangga. 
Ketidakpastian mengenai landas kontinen ini berhasil dirumuskan secara jelas dalam UNCLOS 1982. Konvensi memuat ketentuan-ketentuan baru yang dapat dianggap sebagai perkembangan progresif dari Hukum Laut Internasional, juga memuat ketentuan-ketentuan lama yang telah mendapat perumusan dalam Konvensi Hukum Laut 1958 diantaranya ketentuan mengenai landas kontinen.

Pasal 76 UNCLOS 1982 menyatakan bahwa sebuah negara pantai berhak atas landas kontinen melebihi 200 mil laut atau tidak boleh lebih dari 350 mil laut, yang diukur dari garis pangkalnya. Jika dapat dibuktikan adanya natural prolongation (kepanjangan ilmiah) dari daratan negara pantai itu. Hal ini dikenal dengan istilah landas kontinen ekstensi (LKE). Negara pantai harus melakukan delineasi batas terluar LKE ini dan mengajukannya kepada Komisi Batas Landas Kontinen (Commission on the Limits of Continental Shelf (CLCS)) melalui Sekretaris Jenderal Perserikatan Bangsa-Bangsa (PBB). Hal ini menyebabkan banyak negara berlomba mengklaim teritoril lautnya sesuai dengan hak yang diberikan UNCLOS 1982. Ketentuan yang termuat di dalam konvensi, membuat negara pantai berhak menetapkan batas landas kontinennya lebih dari 200 mil laut.

Indonesia merupakan negara pantai yang memiliki potensi untuk mengajukan Landas Kontinen Ekstensi (LKE). Kajian pendahuluan yang dilakukan beberapa pihak menunjukkan adanya kemungkinan Indonesia dapat mengajukan LKE untuk beberapa wilayah maritim. Dalam hal ini dianalisis status terkini dan tantangan yang dihadapi oleh Indonesia dalam proses delineasi dan pengajuan kepada CLCS. Ada empat tantangan yang dihadapi Indonesia dalam proses ini yaitu tantangan teknis, institusi, finansial, dan politis. Sebagai pengantar, tulisan ini juga memaparkan konsep penentuan LKE sesuai dengan UNCLOS 1982. Permasalahannya bagaimana upaya yang dapat dilakukan Indonesia untuk menetapkan batas landas kontinen di luar 200 mil laut menurut hukum laut internasional?

\section{PEMBAHASAN}

\section{Definisi dan Sejarah Konsepsi Landas Kontinen}

Istilah landas kontinen berasal dari istilah geologi kelautan, untuk menyebutkan kawasan dasar laut dan tanah dibawahnya yang bersambungan dengan pantai yang berada di bawah permukaan laut. Secara lebih lengkap, landas kontinen dalam pengertian geologi ini ditegaskan dalam Encyclopedia America, yang dikutip oleh I Wayan Parthiana, yakni: "Bagian dari dasar samudra atau kelautan yang bersambungan dengan pantai dari suatu benua dan ditutupi oleh perairan dangkal, yaitu kurang dari 80-100 Fatoms (490-600 kaki, atau 145-100 meter)".

Pengertian ini menunjukan gambaran laut (Topografi laut) secara geologis terdiri dari: a. The continental margin yaitu dasar laut yang berbatasan dengan benua atau continent yang mencakup continental shelf, continental slope, dan continental rise, dan b. Abyssal plains atau dasar laut dalam yang tidak lagi merupakan bagian dari continent, meliputi kawasan di luar "continental margin". Pada bagian-bagian tertentu di dasar laut dalam ini terdapat lembah-lembah yang dalam dan curam ("trennch") yang pada bagian lainnya dari dasar laut dalam ini terdapat dasar laut yang bergunung-gunung atau "mountain ranges".

Dari pengertian tersebut istilah continental shelf, continental slope dan continental rice, menurut R.R. Churchil, dapat diartikan sebagai berikut: 1. continental shelf (dataran kontinen), yaitu wilayah dasar laut yang berbatasan dengan benua atau pulau-pulau yang turun ke bawah secara bertahap yang diukur dari garis air rendah sampai kedalaman mencapai 130 meter; 2. continental slope, yaitu wilayah dasar laut yang berbatasan dengan continental shelf yang mempunyai kemiringan yang lebih curam, yang menurun sampai sekitar kedalaman 1500-3500 meter; 3. Continental rise, yaitu bagian dasar laut yang berbatasan dengan continental slope menurun dari kedalaman 3500 meter sampai 5500 meter.

Batasan ini mempunyai persamaan dengan batasan yang dikemukakan Mochtar Kusumaatmadja dalam mengartikan continental margin, yaitu bagian benua di bawah laut yang berbatasan dengan dasar samudera dalam. Tetapi dalam memberikan batasan continental shelf (dataran kontinen) dalam arti geologis dataran kontinen adalah dasar laut (seabed) dan tanah dibawahnya (subsoil), dari daerah di bawah laut yang berdekatan dengan suatu negara hingga kedalaman 200 meter. Demikian juga dengan continental slope dan continental rise, meskipun beliau tidak menyebutkan batas kedalamannya, tetapi dinyatakan bahwa continental margin (continental shelf, continental slope dan continental rise) merupakan bagian-bagian dunia di bawah air (laut) yang berbatasan dengan dasar samudera dalam.

Dengan demikian sesuai dengan namanya sendiri landas kontinen (continental shelf), dari segi ilmu bahasa dapat diartikan juga sebagai landas benua, oleh karena kata continen dialihbahasakan ke dalam bahasa Indonesia sama artinya dengan benua atau kontinen, jadi dengan demikian, dari segi geologi hanya benua sajalah yang memiliki landas kontinen 
sedangkan pulau ataupun gugusan pulau, tidak memiliki landas kontinen.

Istilah landas kontinen dalam ilmu geologi laut ini kemudian diadopsi ke dalam istilah hukum, hal ini dikarenakan dalam hukum laut internasional mulai muncul dan berkembang konsep hukum baru yang berkembang menjadi suatu pranata hukum laut baru yang dalam perkembangannya kemudian kita kenal dengan nama rezim hukum landas kontinen.

Rezim hukum landas kontinen semula berasal dari tuntutan sepihak negara-negara terhadap sumber kekayaan alam yang terletak di luar laut teritorial. Tuntutan terhadap landas kontinen pertamakali berasal dari pemerintah kerajaan Rusia pada tanggal 25 september 1915 namun tuntutan itu kemudian tidak dapat dilanjutkan karena terjadi revolusi di negara tersebut.

Pada tanggal 28 September 1945 Presiden Amerika Serikat, Harry S. Truman mengeluarkan pernyataan tentang klaim Pemerintah Amerika Serikat atas continental shelf yang berbatasan dengan pantai Amerika Serikat.

Adapun landasan teori yang dikemukakan Amerika Serikat untuk mengambil tindakan tersebut, karena continental shelf dapat dianggap sebagai kelanjutan alamiah (natural prolongation) daripada wilayah daratan Amerika Serikat dan bagaimanapun usahausaha untuk mengolah kekayaan yang terkandung didalamnya memerlukan tindakan Amerika Serikat ini tidak mengganggu kebebasan pelayaran di laut lepas yang berada di atas continental shelf.

Dengan memperhatikan konfigurasi dasar laut sebagaimana yang telah dijelaskan, maka doktrin Truman mengenai continental shelf ini merupakan tonggak sejarah dalam perkembangan hukum laut yang didasarkan atas pengertian geologis tentang continental shelf atau dataran kontinen. Proklamasi ini terdiri atas dua hal penting yaitu tentang landas kontinen dan perikanan. Mengenai landas kontinen, Presiden Truman menyatakan bahwa dasar laut dan tanah di bawah dasar laut yang terletak di luar daerah laut teritorial Amerika Serikat dan sumber daya alam yang terkandung didalamnya merupakan sambungan dari daratan Amerika Serikat. Oleh karena itu Amerika Serikat memiliki hak, yuridiksi dan pengawasan atas sumber daya alam yang terkandung didalamnya.

Proklamasi Truman dalam waktu relatif singkat telah mendorong negara-negara pantai lainnya di belahan bumi ini menuntut penguasaan kekayaan alam yang terdapat dalam dasar laut dan tanah di bawahnya (seabed and subsoil) yang berbatasan dengan pantainya.
Tindakan sepihak negara-negara dalam menunjukkan suatu perkembangan baru yang tidak kecil artinya dalam hukum laut internasional. Dapat dikatakan menjelang Konferensi Hukum Laut PBB I tahun 1958 continental shelf ini telah melembaga dalam hukum laut internasional melalui hukum kebiasaan. Karena itu negara-negara peserta konferensi tidak banyak menemui kesukaran dalam merumuskan ketentuanketentuan hukum yang mengatur hak-hak dan kekuasaan Negara pantai atas continental shelf.

\section{Landas Kontinen (Continental Shelf) menurut UNCLOS}

1. Landas Kontinen dalam Konvensi Hukum Laut 1958.

Pengertian Landas Kontinen (LK) dalam UNCLOS 1958 adalah pengertian dalam arti hukum LK yang berbeda dengan pengertian aslinya menurut Proklamasi Truman. Secara lengkap pengertian landas kontinen dimuat dalam UNCLOS 1958 pasal 1, yang berbunyi:

"For the purpose of these articles, the term "continental shelf" is used as referring; $a$. to the seabed and subsoil of the submarine areas adjacent to the coast but autside the area of the territorial sea, to a depth of 200 metres or beyond that limit, to where the superjecent waters admits of the exploitation of the natural resources of the said areas; $b$. to seabed and subsoli of similar submarine areas adjacent to the coast of islands.

Pengertian LK yang diatur UNCLOS 1958 adalah pengertian landas kontinen dalam arti yuridis, yang sangat berbeda dengan pengertian landas kontinen dalam arti geologis seperti yang telah disebutkan sebelumnya. Sifat yuridis dari pengertian landas kontinen ini ditujukan dengan pembatasan-pembatasan, yakni: a. Yang termasuk dalam ruang lingkup landas kontinen itu hanyalah meliputi dasar laut dan tanah dibawahnya yang bersambungan dengan pantai yang terletak di luar area laut teritorial; b. Sifat yuridis lainnya dapat ditujukan pada penegasan tentang perluasan landas kontinen tersebut yakni, tidak saja benua yang memiliki landas kontinen tetapi juga pulau.

Kalau dilihat dari sejarah, ketentuan ini merupakan kompromi antara negara-negara yang berpendirian bahwa LK dalam arti Konvensi (yuridis) hanya pada LK dalam arti geologis, yaitu pada ukuran kedalaman 200 meter (Inggris, Libanon, Belanda dan Perancis) dan Negara-negara yang hendak memakai kriteria technical exploitability (Argentina, Korea dan Panama), maka tambahan kata-kata “... or beyond that limit" harus dianggap sebagai alternatif yang 
dapat menggantikan kriterium dalam laut (hingga 200 meter) seandainya tidak terdapat dataran kontinen dalam arti geologis.

Ternyata dengan kemajuan teknologi di bidang kelautan yang sangat pesat, interprestasi ketentuan pasal 1 tersebut di atas hanya ditekankan pada ukuran technical exploitability, sehingga batas yang dicapai oleh teknik pengambilan kekayaan di laut. Karena itu ketentuan LK dalam pasal 1 UNCLOS 1958 tersebut (kriteria technical exploitability) sudah tidak memuaskan lagi terutama bagi negara-negara yang sedang berkembang dan tidak mempuyai kemampuan dan teknologi untuk memanfaatkannya. Ketentuan inilah yang merupakan salah satu alasan untuk meninjau kembali UNCLOS 1958 agar mengenai landas kontinen diberikan batas terluar yang jelas.

\section{Landas Kontinen Menurut UNCLOS1982}

UNCLOS 1982 memuat ketentuan-ketentuan baru yang dapat dianggap sebagai perkembangan progresif dari Hukum Laut Internasional, juga memuat ketentuan-ketentuan lama yang telah mendapat perumusan dalam UNCLOS 1958 diantaranya ketentuan mengenai landas kontinen. Konsep yang banyak dipermasalahkan dalam UNCLOS 1982 adalah konsep landas kontinen, terutama dengan diajukannya konsepsi Zona Ekonomi Eksklusif (ZEE) 200 meter, telah menimbulkan perbedaan pendapat antara kelompokkelompok peserta.

Dalam perkembangannya negara-negara ini merasa berhak atas segala yang dituntut oleh negara-negara pantai, karena mereka merupakan bagian dari " $m i n-$ kind", oleh karena itu mereka juga menuntut hak yang sama untuk mengambil kekayaan alam di Zona Ekonomi Eksklusif (ZEE) dan atau di Landas Kontinen (LK).

Permasalahan yang muncul dalam konferensi UNCLOS 1982 antara lain, bagaimana menentukan batas LK, di satu sisi konsep ZEE telah diterima itu berarti dengan sendirinya batas LK minimum adalah 200 mil di ukur dari dari garis pangkal laut teritorial, akan tetapi beberapa negara yang memiliki margin yang luas seperti Amerika Serikat, Inggris dan Uni Soviet enggan untuk melepaskan klaim atas sumber kekayaan alam yang berada di "margin" yang terluar atau di luar 200 mil, sedangkan negara-negara yang memiliki margin sempit kurang dari 200 mil setuju dengan batas landas kontinen sejauh 200 mil.

Rezim LK dengan kesepakatan negara-negara peserta konferensi hukum laut 1982 menetapkan aturan tentang landas kontinen, dimuat dalam BAB VI, pasal 76-85. Pengertian landas kontinen perumusannya dimuat secara lengkap dalam pasal 76 yang menyatakan sebagai berikut: "Landas Kontinen suatu negara pantai meliputi dasar laut dan tanah dibawahnya dari daerah di bawah permukaan laut yang terletak di luar laut teritorialnya sepanjang kelanjutan alamiah wilayah daratannya hingga pinggiran luar tepian kontinen, atau hingga suatu jarak 200 mil laut dari garis pangkal darimana lebar laut teritorial diukur, dalam hal pinggiran tepian kontinen tidak mencapai jarak tersebut".

Dari ketentuan pasal 76 ayat (1) tersebut terlihat dua cara pengukuran landas kontinen, yaitu: a. Sampai batas terluar tepian kontinen (the continental margin); b. Sampai jarak 200 mil dari garis pangkal laut teritorial, apabila tepian kontinen tidak mencapai jarak tersebut.

Selanjutnya dalam ayat (3) konvensi menyebutkan, tepian kontinen meliputi kelanjutan bagian daratan negara pantai yang berada di bawah air, dan terdiri dari dasar laut dan tanah dibawahnya dari daratan kontinen, lereng (slope) dan tanjakan (rise). Tepian kontinen yang dimaksud tidak mencakup dasar samudera dalam dengan bukit-bukit samudera atau tanah dibawahnya.

Selanjutnya dinyatakan, apabila tepian kontinen yang dimaksud dalam ayat (1) tersebut lebih besar dari 200 mil dari garis pangkal darimana laut teritorial, maka pasal 76 ayat (4a) konvensi menyatakan negara pantai akan menetapkan pinggiran luar tepian kontinen, dengan cara yang ditetapkan dalam ayat 4a (i), (ii) dan b yaitu: a. (i) suatu garis yang ditarik sesuai dengan ayat 7 dengan menunjuk pada titik-titik tetap terluar dimana ketebalan batu endapan adalah paling sedikit $1 \%$ dari jarak terdekat antara titik tersebut dan kaki lereng kontinen; atau (ii) suatu garis yang ditarik sesuai dengan ayat 7 dengan menunjuk pada titik-titik tetap yang terletak tidak lebih $60 \mathrm{mil}$ laut dari kaki lereng kontinen; b. Dalam hal tidak terdapatnya bukti yang bertentangan kaki lereng kontinen harus ditetapkan sebagai titik perubahan maksimum dalam tanjakan pada kakinya.

Penentuan titik tetap batas terluar tepian kontinen tidak boleh melebihi 350 mil laut dari garis pangkal laut teritorial dan tidak boleh melebihi 100 mil laut dari garis batas kedalaman (isobath) 2500 meter.

Pasal 76 ayat (6) menetapkan meskipun penetapan garis batas terluar tepian kontinen tidak boleh melebihi 350 mil laut lepas dari garis pangkal laut teritorial, ketentuan ini tidak berlaku lagi bagi elevasi dasar laut yang merupakan bagian-bagian alamiah tepian kontinen, seperti pelataran (plateau), tanjakan (rise), puncak (caps), ketinggian yang datar (banks) dan puncak gunung yang bulat (spurs)nya. 
Melihat penjelasan pasal UNCLOS 1982 di atas, untuk mengukur lebar LK dapat ditentukan dengan beberapa alternatif, yaitu: a. Lebar landas kontinen diukur sampai batas terluar tepian kontinen (the continental margin); b. Lebar landas kontinen, sampai jarak 200 mil laut dari garis pangkal laut teritorial apabila tepian kontinen tidak melebihi 200 mil laut; c. Lebar landas kontinen sampai jarak 350 mil laut dari garis pangkal laut teritorial apabila tepian kontinen melebihi 200 mil laut, atau; d. Tidak boleh melebihi 100 mil laut dari garis kedalaman (isobath) 2500 meter.

Dengan demikian berarti lebar LK dari suatu negara pantai tergantung pada konfigurasi tepian kontinen (continental margin)nya. Oleh karena itu suatu negara pantai dapat menetapkan lebar LK yang berbeda-beda di sekeliling laut wilayahnya.

Perumusan dalam pasal 76 UNCLOS 1982 memberikan ketentuan yang lebih jelas dalam cara mengukur lebar landas kontinen jika dibandingkan dengan UNCLOS 1958, karena pasal 76 konvensi merupakan penyempurnaan dalam memberikan pengertian Landas Kontinen. Penyempurnaan yang dimaksud dalam konvensi 1982, yaitu: a. Terdapat kepastian dalam pengukuran batas terluar landas kontinen berdasarkan alternatif-alternatif sebagaimana tercantum dalam pasal 76. Dengan demikian menghapuskan ketidakjelasan cara pengukuran yang didasarkan atas kriteria "technical exploitability" yang terdapat dalam UNCLOS 1958; b. Pengertian landas kontinen yang terdapat dalam rumusan pasal 76 selain mencakup pengertian yuridis juga mencakup pengertian geologis.

UNCLOS juga mengatur tentang hak dan kewajiban negara di LK, hak negara di LK, antara lain; a. Hak untuk mengeksplorasi dan mengeksploitasi; $b$. Hak untuk memasang kabel dan pipa saluran; c. Hak membangun dan mengunakan pulau-pulau buatan, instalasi-instalasi dan bangunan pada atau di atas LK; d. Hak untuk memberikan kewenangan melakukan pengeboran pada LK; e. Hak untuk mencegah, mengurangi dan mengendalikan pencemaran lingkungan laut.

Selain hak-hak yang dimiliki negara pantai juga mempunyai kewajiban berdasarkan konvensi, antara lain: a. Kewajiban untuk menghormati kaidah-kaidah hukum laut internasional yang berlaku pada LK.; b. Negara pantai wajib menghormati hak-hak negara lain di LK seperti hak negara atau pihak lain untuk memasang pipa saluran atau kabel di bawah laut dan tidak boleh menghalang-halangi atau pun menghambat negara atau pihak lain untuk memasang pipa-pipa saluran di LK.; c. Kegiatan eksplorasi dan eksploitasi yang dilakukan oleh negara-negara atau pun pihak lain pada LK berdasarkan ijin atau persetujuan, dari negara pantai, negara pantai juga berkewajiban untuk menghormatinya, misalnya dengan tidak melakukan tindakan yang bertentangan dengan hak-hak yang telah diberikannya kepada negara atau pihak ketiga tersebut; d. Negara pantai berkewajiban membayar sejumlah pembayaran atau sumbangan melalui otorita dasar laut.

Selain hak dan kewajiban yang dimiliki oleh negara atas LK, UNCLOS juga mengatur hak dan kewajiban negara lain di atas LK, antara lain; a. Kebebasan berlayar dan penerbangan; b. Kebebasan untuk memasang kabel dan pipa bawah laut; c. Hak untuk menangkap ikan; d. Kebebasan untuk melakukan riset ilmiah.

\section{Penetapan Batas Landas Kontinen antar Negara}

Penetapan garis batas landas kontinen antara dua negara yang berdampingan (adjacent) atau pun berhadapan (opposite) tidaklah mudah dikarenakan konfigurasi pantai dari negara pantai (costal states) atau negara pulau (island states) maupun negara kepulauan (achipelagic states) yang cenderung tidak teratur serta struktur geologi dasar laut dan tanah dibawahnya yang sangat kompleks.

UNCLOS 1958 mengatur tentang batas landas kontinen antara dua negara atau lebih pada pasal 6 ayat $(1,2,3)$ dan pasal 7 . Dari diskripsi pasalpasal terdapat empat cara untuk menetapkan garis batas landas kontinen, antara lain: a. Dengan cara membuat perjanjian dan persetujuan antara negaranegara pantai yang berkepentingan; $b$. Penentuan garis batas LK berdasarkan penerapan metode garis tengah (median line); c. Penentuan garis batas LK berdasarkan penerapan jarak sama (equidistance principle); d. Penentuan garis batas LK dengan cara lain yang dibenarkan berdasarkan keadaan khusus (special circumstances).

Pengaturan tentang garis batas landas kontinen antara dua negara atau lebih yang berdampingan atau berhadapan dalam UNCLOS 1982 diatur dalam pasal 83 yang terdiri dari 4 ayat, pasal ini menekankan tentang penyelesaian garis batas landas kontinen, antara lain: a. Dengan cara persetujuan dan perjanjian antara dua negara atau lebih, sebagaimana yang tercantum dalam pasal 38 Statuta Mahkamah Internasional; b. Jika dalam waktu yang dipandang layak belum dapat diselesaikan dengan perjanjian dan persetujuan maka harus dilakukan dengan cara penyelesaian sengketa 
yang diatur dalam bagian XV konvensi; c. Para pihak yang berkepentingan selama belum tercapai kesepakatan seperti yang ditentukan dalam ayat 1 untuk melakukan usaha-usaha guna mengadakan pengaturan sementara yang bersifat praktis.

Diantara ketiga jenis sumber hukum yang utama, biasanya yang diberi tempat pertama adalah perjanjian internasional umum maupun khusus yang secara tegas diterima oleh negara-negara yang bersangkutan, tetapi jika tidak ada perjanjian internasional umum maupun khusus, maka akan dipakai hukum kebiasaan, dan apabila tidak ada maka dipakai azas prinsip hukum umum yang diakui oleh bangsa-bangsa. Jika ketiga kategori tidak ada yang bisa diterapkan untuk menyelesaikan suatu persoalan maka akan digunakan keputusan-keputusan pengadilan.

Apabila penyelesaian ini tidak dapat dicapai dalam waktu yang layak, negara yang bersangkutan harus menggunakan prosedur yang ditentukan dalam pasal 33 ayat (1) Piagam PBB, seperti negoisasi, penyelidikan, konsiliasi, arbitrasi, penyelesaian secara hukum melalui badan-badan regional atau persetujuan atau cara-cara yang dipilih (pasal 83 ayat (1). Selain caracara tersebut dapat juga dilakukan melalui mahkamah permanen internasional seperti, Mahkamah Internasional Hukum Laut, Mahkamah Internasional, Mahkamah Arbitrasi dan Mahkamah Arbitrasi Khusus.

Kepada negara pantai diwajibkan mencantumkan garis batas luar landas kontinen dan garis penetapan batas yang ditentukan dalam persetujuan yang ditetapkan di antara negara-negara yang berdampingan atau berhadapan pada skala yang memadai untuk menentukan posisinya.

\section{Pengajuan Penetapan Batas Landas Kontinen di Luar 200 Mil Laut}

Penentuan batas landas kontinen dapat dibagi menjadi empat kondisi, yaitu: 1. Penentuan batas LK kurang dari 200 mil laut. Batas terluar dari LK adalah sejauh 200 mil laut atau berhimpit dengan batas ZEE. Konsep ini dikenal dengan Coextensive Principle; 2. Penentuan batas LK lebih dari 200 mil laut. Batas terluar LK mengacu pada empat ketentuan penentuan pinggiran luar tepian kontinen; 3 . Penentuan batas LK yang berbatasan dengan negara pantai lainnya. Batas terluar LK mengacu pada perjanjian antara negara yang berkepentingan; 4 . untuk menentukan batas LK sesuai dengan UNCLOS 1982, diperlukan pemahaman lebih lanjut mengenai garis pangkal, kaki lereng kontinen, pinggiran luar tepian kontinen, dan punggungan atau penampakan dasar (ridges).
Berdasarkan UNCLOS 1982, penentuan batas Landas Kontinen Ekstensi (LKE) dapat dilakukan dengan memperhatikan 4 (empat) ketentuan seperti yang diatur dalam pasal 76 . Dua kriteria pertama adalah kriteria yang memperbolehkan (Formulae) sedangkan 2 (dua) kriteria terakhir adalah kriteria yang membatasi (constraints). Kriteria yang memerbolehkan, antara lain: 1. Didasarkan pada titik tetap terluar pada titik dimana ketebalan batu endapan (sedimentary rock) paling sedikit 1\% dari jarak terdekat antara titik tersebut dengan kaki lereng kontinen. Dalam TALOS, garis ini diistilahkan dengan Gardiner line. Dengan kata lain, batas terluar LKE adalah garis yang menghubungkan titik-titik dengan ketebalan batu sedimen 1\% dihitung dari kaki lereng kontinen. Persentase ini dihitung dengan membandingkan tebalnya batu sedimen di suatu titik terhadap jarak titik tersebut dari kaki lereng; 2. Batas terluar LKE juga bisa ditentukan dengan menarik garis berjarak 60 mil laut dari kaki lereng kontinen atau hedberg line ke arah laut lepas.

Penerapan batas terluar LKE merupakan kombinasi dari dua syarat di atas, yang dalam hal ini akan dipilih garis terluar yang paling menguntungkan negara bersangkutan. Namun demikian garis terluar belumlah merupakan garis batas LKE final karena masih harus diuji dan memenuhi dua syarat pembatas seperti di jelaskan di bawah ini. Syarat membatasi antara lain: 1. Batas terluar dari LK tidak boleh melebihi 350 mil laut dari garis pangkal, sebagai referensi mengukur batas teritorial; atau 2. Batas terluar dari LK tidak boleh melebihi 100 mil laut dari kontur kedalaman $2500 \mathrm{~m}$ isobat.

Seperti halnya dua syarat yang membolehkan, kedua syarat yang membatasi ini pun bisa berlaku salah satu yang paling menguntungkan atau garis terluar yang dihasilkan. Dengan kata lain adalah tidak benar jika dikatakan bahwa lebar LKE maksimum adalah 350 mil laut karena seringkali garis kedalaman 2500 meter isobat terletak lebih jauh (dari garis pangkal) dibandingkan garis 3500 mil laut. ini berarti batas terluar landas kontinen ekstensi bisa lebih dari 350 mil dari garis pangkal.

Akan tetapi mempersiapkan pengajuan LKE tentu saja bukanlah pekerjaan yang mudah. Ada banyak tantangan yang dihadapi sebuah negara pantai meliputi aspek teknis, institusi, finansial, dan politis. Pasal 76 UNCLOS 1982 menyatakan bahwa negara pantai berhak atas LK melebihi 200 mil laut, yang diukur dari garis pangkalnya. Negara pantai harus melakukan delineasi batas terluar LKE dengan mengajukannya kepada Komisi Batas Landas Kontinen (Commission 
on the Limits of Continental Shelf, CLCS) melalui Sekretaris Jenderal Perserikatan Bangsa-Bangsa.

Sesuai dengan ketentuan pasal 76 maka dibentuklah Lampiran II UNCLOS untuk mengakomodasi pembentukan CLCS. Fungsi dan peran CLCS serta prosedur pengajuan LKE oleh Negara pantai diatur dalam Rules of Procedure of the Commission on the Limits of the Continental Shelf (CLCS, 2004). CLCS terdiri atas 21 orang ahli di bidang Geologi, Hidrografi, Oseanografi dan Geodesi, yang terdistribusi secara adil mewakili kawasan geografis negara anggota UNCLOS. Pemilihan anggota CLCS termutakhir dilakukan bulan Juni 2007 untuk masa tugas 2007-2012. Untuk keanggotaan CLCS terbaru, ada lima anggota yang terpilih mewakili Asia yaitu dari India, China, Korea Selatan, Jepang, dan Malaysia. Masing-masing anggota akan bertugas atas nama dan dalam kapasitas pribadi.

Negara-negara pantai yang memiliki peluang LKE harus melakukan delineasi dan bersiap-siap untuk mengajukan landas kontinennya kepada CLCS. Negara pantai diharus mendepositkan informasi batas LK negaranya kepada Sekretaris Jenderal PBB, dalam bentuk peta-peta dan keterangan-keterangan yang relevan, termasuk data geodesi yang secara permanen menggambarkan batas luar kontinennya. Dokumen batas landas kontinen terbagi atas dokumen batas landas kontinen kurang dari 200 mil laut dan dokumen batas landas kontinen lebih dari 200 mil laut.

Khusus untuk batas landas kontinen yang diklaim lebih dari 200 mil laut dari garis pangkal oleh suatu negara pantai, terdapat ketentuan tambahan yang perlu dipenuhi, yaitu kewajiban untuk menyampaikan keterangan mengenai batas-batas landas kontinen kepada Komisi tentang Batas Landas Kontinen (Commision on the Limits of the Continental Shelf).

Data dan dokumen yang harus disiapkan oleh negara pantai untuk mengklaim batas landas kontinen lebih dari 200 mil laut, berupa sumber data, teknik survei penentuan posisi, tanggal dan waktu survey, koreksi yang diberikan terhadap data, ketelitian apriori dan aposteriori terhadap kesalahan acak dan kesalahan sistematik, sistem referensi geodetik, definisi geodetik tentang garis pangkal lurus, kepulauan, dan penutup.

Data dan dokumen yang harus diserahkan kepada CLCS berkaitan dengan penentuan garis kedalaman 2500 meter terdiri, dari sumber data, teknik pemeruman yang dilaksanakan, sistem referensi, geodetik, metode penentuan posisi navigasi dan kesalahankesalahannya, tanggal dan waktu survey, koreksi yang diberikan terhadap data, ketelitian apriori dan aposteriori terhadap kesalahan acak dan kesalahan sistematik.

Data dan dokumen yang harus disiapkan apabila seluruh garis pembatas 350 mil laut digunakan dalam mendefinisikan batas terluar dari LK, adalah: 1. Sumber data; 2. Teknik penentuan posisi geodetik dan sistem referensinya; 3 . Koreksi yang diberikan terhadap data; 4. Definisi geodetik dalam hal garis pangkal lurus, kepulauan, dan penutup; 5. Ketelitian apriori dan aposteriori terhadap kesalahan acak dan kesalahan sistematis; 6. Sistem referensi geodetik.

Dokumen klaim yang diajukan untuk mendukung penentuan batas terluar landas kontinen suatu negara pantai, mencantumkan satu dari lima kemungkinan kasus pada sembarang titik pada garis batas, yaitu: 1 . Garis yang dilukiskan pada jarak 60 mil laut dari kaki lereng kontinen; 2. Garis sepanjang dimana ketebalan batu endapan sebesar satu persen dari jarak terdekat dari kaki lereng.

Sedangkan kriteria pembatasnya adalah: a. Garis yang dilukiskan pada jarak 350 mil laut dari garis pangkal, atau b. Garis yang dilukiskan pada jarak 100 mil laut dari garis kedalaman 2500 meter; c. Batas yang disetujui oleh negara-negara pantai yang berhadapan dan berdampingan.

CLCS bertanggung jawab untuk mempertimbangkan pengajuan klaim LKE yang dilakukan oleh negara pantai, membuat rekomendasi atas pengajuan tersebut serta menyediakan bantuan yang bersifat ilmiah dan teknis, jika diminta, terkait persiapan pengajuan LKE oleh negara pantai.

Prosedur pengajuan LKE diatur dalam Pasal 76 $(8,9)$ UNCLOS yang menyatakan bahwa batas terluar Landas Kontinen harus diserahkan kepada CLCS (ayat 8). Selanjutnya adalah tugas CLCS untuk mempertimbangkan dan membuat rekomendasi atas pengajuan tersebut kepada negara pantai yang bersangkutan. Ayat 9 Pasal 76 menambahkan bahwa pengajuan ini harus disertai dengan peta laut dan informasi relevan lainnya, termasuk data geodesi yang secara permanen mendeskripsikan batas terluar LK.

Setelah semua informasi yang dibutuhkan untuk mengklaim batas landas kontinen tersebut dipenuhi, informasi yang dimaksud akan diperiksa oleh CLCS kebenarannya. Apabila CLCS telah mengesahkan batas landas kontinen yang diklaim negara pantai bersangkutan, maka semua data dan informasi yang dimaksud dalam ayat 9 harus diserahkan kepada Sekretaris Jenderal Perserikatan Bangsa-Bangsa yang kemudian mengumumkan pengajuan ini dalam batas waktu yang ditentukan. 
Keuntungan pengajuan LKE, yang bisa dipertimbangkan negara yaitu deklarasi hak berdaulat dan potensi ekonomi jangka panjang. Dengan berlakunya UNCLOS 1982 yang memungkinkan setiap negara pantai mengklaim landas kontinen melebihi 200 mil, maka ada kecenderung untuk menguasai seluas mungkin landas kontinen sepanjang persyaratan legal dan teknis terpenuhi.

Dengan situasi ini, sebuah negara pantai harus menyatakan klaimnya untuk mengantisipasi sengketa di masa depan. Landas kontinen menyimpan potensi ekonomi yang sangat besar. Minyak dan gas bumi adalah dua hal yang paling utama selain cadangan mineral lainnya. Dengan mengajukan LKE maka negara pantai berpeluang untuk bisa memanfaatkan sumberdaya alam yang ada pada dan di dalam LK untuk kepentingan negara dan rakyat negara pantai tersebut.

\section{Upaya Pengajuan Batas Landas Kontinen Eks- tensi Indonesia}

Indonesia merupakan salah satu negara pantai yang mempunyai prospek untuk mengajukan LKE. Sampai hari ini Indonesia belum mengajukan LKE kepada CLCS meskipun telah melakukan delineasi untuk kawasan tertentu. Ada beberapa hal yang dapat dianalisis berkaitan dengan penetapan batas LK Indonesia, yaitu dari segi hukum dan segi teknis. Disamping itu, dilakukan analisis juga terhadap perjanjian batas yang telah ada antara Indonesia dan negara tetangga.

Pada tanggal 17 Februari 1969, pemerintah Indonesia mengeluarkan pengumuman tentang Landas Kontinen Indonesia yang kemudian dikukuhkan menjadi UU No. 1 tahun 1973 untuk mendapatkan kepastian hukum serta dasar bagi pelaksanaan hak-hak eksploitasi pada landas kontinen. Berdasarkan UU ini, LK Indonesia didefinisikan sebagai dasar laut dan tanah dibawahnya di luar perairan wilayah Republik Indonesia sebagaimana diatur dalam Undang-Undang Nomor 4 Tahun 1960 sampai kedalaman 200 meter atau lebih, dimana masih mungkin diselenggarakan eksplorasi dan eksploitasi kekayaan alam. Pemerintah Republik Indonesia mengeluarkan UndangUndang Nomor 17 Tahun 1985 sebagai ratifikasi atas UNCLOS 1982.

Dari segi hukum terutama berkaitan dengan definisi LK UNCLOS 1982 telah berlaku efektif sejak tanggal 16 Nopember 1994, akan tetapi masih banyak negara pantai yang belum menerapkan ketentuan UNCLOS 1982 dan masih menerapkan ketentuan pada UNCLOS 1958. Terdapat perbedaan yang mendasar antara definisi LK berdasarkan UNCLOS 1958 dan UNCLOS 1982. Pada UNCLOS 1958, definisi yang diberikan pada dasarnya masih mengacu pada definisi dari istilah geologis, sedangkan pada UNCLOS 1982 definisi landas kontinen berubah menjadi istilah hukum yang disesuaikan dengan perkembangan teknologi eksplorasi dan eksploitasi. Batas LK berdasarkan kedalaman yang diberikan UNCLOS 1958 sejauh 200 meter menjadi tidak berlaku dan digantikan dengan tepian kontinen pada UNCLOS 1982. Peraturan nasional yang berlaku sekarang, berkaitan dengan LK Indonesia adalah UU Nomor 1 Tahun 1973. Dengan adanya UU Nomor 17 Tahun 1985 tentang ratifikasi UNCLOS 1982, Indonesia seharusnya mencabut UU Nomor 1 Tahun 1973, karena masih mengacu pada definisi LK berdasarkan UNCLOS 1958, dan menggantinya dengan undang-undang baru yang sesuai dengan UNCLOS 1982, sehingga Indonesia mempunyai dasar hukum yang kuat untuk mengatur LK Indonesia.

Dari segi teknis analisis dikaitkan dengan, Garis Pangkal, Mil Laut, Survei Batimetri, Penentuan Kaki Lereng, Penentuan Ketebalan Batu Endapan Satu Persen dan Batasan Terluar Landas Kontinen. Selain analisis teknis dan yuridis Indonesia harus menyelesaikan persoalan perjanjian perbatasan antara negaranegara tetangga yang berhadapan atau berdampingan. terhadap perjanjian yang telah ada berkaitan dengan Landas Kontinen Indonesia dapat dirangkum sebagai berikut:

a. Indonesia - Australia

Perjanjian yang dibuat antara Indonesia dengan Australia menghasilkan ketentuan yang merugikan Indonesia. Kerugian tersebut muncul karena tidak ditegakkannya prinsip co-extensive principle. Batas landas kontinen Australia masuk ke dalam batas ZEE Indonesia, hal ini menyebabkan batas landas kontinen lebih dekat ke pantai Indonesia. Dengan ditegakkannya co-extensive principle batas landas kontinen Indonesia seharusnya berimpit dengan batas ZEE.

b. Indonesia - Malaysia

Perjanjian batas landas kontinen dengan Malaysia masih menggunakan UNCLOS 1958 sebagai acuan. Terdapat persetujuan yang merugikan Indonesia dimana garis batas LK antara kedua negara lebih dekat ke pantai Indonesia di Selat Malaka (perjanjian menggunakan prinsip median line).

c. Indonesia - Vietnam

Perjanjian antara Indonesia dengan Vietnam belum dapat menyelesaikan batas LK kedua negara. Jarak antar pulau yang berdekatan antara kedua negara tidak lebih dari 245 mil laut. Vietnam bersikeras untuk 
tidak menggunakan UNCLOS 1982 sebagai acuan secara menyeluruh.

d. Indonesia - Palau

Untuk menarik suatu batas ZEE yang adil, mengingat jarak antara Pulau Helen (pulau paling Selatan Palau) dengan Pulau Fani/P.P. Asia kurang dari 400 mil laut, maka sebaiknya diterapkan metode sama jarak (equidistance).

e. Indonesia - Philipina

Perjanjian Indonesia dan Philipina masih belum berhasil menetapkan batas LK antara kedua negara. Tertundanya perjanjian antara kedua negara ini lebih disebabkan karena belum akuratnya titik pangkal yang digunakan oleh Philipina. Akan tetapi berdasarkan jarak antara kedua negara di Utara Sulawesi kemungkinan besar perundingan penentuan batas LK antara kedua negara ditetapkan berdasarkan prinsip median line. Selain itu Indonesia juga harus segera menyelesaikan perjanjian perbatasan LK dengan negara-negara tetangga yang sampai hari ini belum terselesaikan.

Penentuan batas terluar LK melebihi $200 \mathrm{mil}$ dari garis pangkal merupakan salah satu agenda yang dikemukakan dalam Laporan Kinerja Dua Tahun Pemerintahan Indonesia. Hal ini dipandang oleh pemerintah sebagai salah satu agenda penting dalam rangka mewujudkan Indonesia yang aman dan damai. Lokakarya teknis dan legal telah dilakukan dengan melibatkan institusi pemerintah dan akademisi. Pemerintah juga telah membentuk tiga organisasi terkait pengajuan LKE. Ketiganya adalah Technical Core Group (TCG) yang beranggotakan pakar-pakar dari institusi dan universitas terkait dan bersifat lintas bidang; National Steering Committee (NSC) dan Legal Group (LG).

Untuk keperluan penetapan batas LK Indonesia perlu melakukan sejumlah kegiatan survei dan pengukuran, yang meliputi survei batimetrik untuk penentuan garis kedalaman $2500 \mathrm{~m}$ dan interpretasi morfologi dasar laut, serta survei seismik untuk mengetahui ketebalan batu endapan.

Para ilmuwan Indonesia dari instansi terkait telah memulai persiapan pengajuan LKE Indonesia sejak tahun 2001. Penelitian dan kajian awal (desktop study) yang dilakukan beberapa pakar Indonesia menunjukkan bahwa ada peluang mengajukan LKE untuk tiga daerah berbeda yaitu di sebelah barat Sumatera, di sebelah selatan Pulau Sumba dan di sebelah utara Papua (Sutisna dkk, 2005). Sementara itu, secara institusi, Badan Koordinasi Survey dan Pemetaan Nasional (Bakosurtanal) telah melakukan delineasi dan persiapan pengajuan LKE bekerjasama dengan BPPT, LIPI, DKP, P3GL, Jawatan Hidro-Oseano- grafi TNI AL dan Kementrian Luar Negeri. Informasi resmi dari Bakosurtanal menegaskan Indonesia berpeluang mengajukan LKE di sebelah barat Aceh, sebelah selatan Jawa dan Nusa Tenggara serta sebelah utara Papua. Dari ketiganya, kawasan sebelah utara Papua belum diverifikasi dan rencananya akan di survei oleh Bakosurtanal.

Mempersiapkan pengajuan landas kontinen ekstensi tentu saja bukanlah pekerjaan yang mudah. Ada banyak tantangan yang dihadapi sebuah negara pantai meliputi aspek teknis, institusi, finansial, dan politis. Dalam perspektif teknis, pelaksanaan survei lapangan merupakan tahap yang paling menantang. Tim LKE Indonesia menghadapi beberapa kesulitan teknis seperti ketersediaan dan kapabilitas kapal survei serta peralatan teknis untuk akuisisi data lapangan. Tantangan ini bisa diatasi, salah satunya, dengan berkolaborasi dengan pihak eksternal seperti German Sonne - BGR dan institusi lain yang memilki kapabilitas teknis yang diperlukan. Hal ini sudah dilakukan dalam beberapa survei teknis seperti dijelaskan sebelumnya. Meski demikian, isu pendanaan dan kerahasiaan data tentu saja merupakan dua hal yang harus dipertimbangkan secara cemat.

Selain pentingnya isu mengenai aspek teknis dan legal terkait pengajuan LKE, hal lain yang harus diperhatikan adalah dimensi politis. Hal khusus yang mungkin akan mendatangkan kesulitan tersendiri adalah dalam hal meyakinkan anggota Dewan Perwakilan Rakyat (DPR) tentang pentingnya pengajuan ini. Meski demikian, keuntungan yang akan diperoleh dari pengajuan LKE bukanlah sesuatu yang dapat dirasakan secara langsung dan dalam waktu sekejap. Hal ini bukanlah proses yang bisa dinilai dengan segera (instant). Pengajuan LKE merupakan suatu investasi jangka panjang untuk masa depan, untuk oportunitas yang mungkin bisa dinikmati oleh generasi penerus Indonesia suatu saat.

Dalam hal potensi keuntungan pengajuan LKE, ada dua hal utama yang bisa dipertimbangkan yaitu deklarasi hak berdaulat dan potensi ekonomi jangka panjang. Dengan berlakunya UNCLOS 1982 yang memungkinkan setiap Negara pantai mengklaim LK melebihi 200 meter, maka ada kecenderung untuk menguasai seluas mungkin LK sepanjang persyaratan legal dan teknis terpenuhi. Dengan situasi ini, sebuah negara seperti Indonesia harus menyatakan klaimnya untuk mengantisipasi sengketa di masa depan.

Terkait masalah ekonomi, landas kontinen menyimpan suatu potensi ekonomi yang sangat besar. Minyak dan gas bumi adalah dua hal yang paling utama selain cadangan mineral lainnya. Dengan 
mengajukan landas kontinen ekstensi maka Indonesia berpeluang untuk bisa memanfaatkan sumberdaya alam yang ada pada dan di dalam landas kontinen ekstensi.

\section{PENUTUP}

\section{Kesimpulan}

Berdasarkan uraian di atas dapat disimpulkan beberapa hal yang berkaitan dengan penetapan Batas Landas Kontinen Indonesia, yaitu: UNCLOS 1982, memberikan kesempatan kepada negara pantai untuk melebarkan wilayah landas kontinennya melebihi 200 mil laut tetapi tidak boleh melebihi 350 mil laut berdasarkan geografisnya. Berdasarkan lampiran II UNCLOS 1982. Negara pantai harus melakukan delineasi batas terluar LKE dengan mengajukannya kepada Komisi Batas Landas Kontinen (Commission on the Limits of Continental Shelf (CLCS)) melalui Sekretaris Jendral PBB.

Sebagai negara pantai Indonesia memiliki kesempatan mengajukan LKE sampai 350 mil laut. Untuk itu Indonesia perlu merevisi UU Nomor 1 Tahun 1973, agar Indonesia mempunyai dasar hukum yang kuat untuk mengatur LK Indonesia. Perjanjian batas LK antara Indonesia dengan negara sekitarnya umumnya masih didasarkan pada UNCLOS 1958, sehingga perlu dikaji secara seksama apakah perlu untuk merevisi perjanjian, terutama pertimbangan kerugian Indonesia akibat perjanjian yang telah ada.

Dari aspek teknis, persoalan utama yang dihadapi adalah masalah biaya untuk keperluan survei. Semua data dan dokumen terkait (peta dan keterangan lainnya) yang mengidentifikasikan tepian kontinen terutama untuk mengklaim batas landas kontinen yang melebihi 200 mil laut dari garis pangkal, akan membutuhkan biaya yang sangat besar. Perlu inventarisasi ulang semua data yang telah ada, terutama yang telah dikumpulkan oleh Dishidros, Bakosurtanal, PPGL, dan perusahaan-perusahaan eksplorasi lepas pantai. Berdasarkan jenis survei yang perlu dilakukan untuk penetapan batas LK, terlihat peran yang besar bagi Surveyor, Geodetic Engineer, dan Hydrographer. Bagi kalangan akademisi, perlu penelitian seksama mengenai pemodelan topografi dasar laut tiga dimensi.

\section{Rekomendasi}

Pengaruh perkembangan teknologi kelautan menjadikan laut sebagai sasaran untuk mendapatkan sumber mineral minyak dan gas bumi yang berada di bawah yuridiksi negara pantai sampai ketepian kontinen (continental margin) dan bahkan melampaui batas itu, melihat kondisi tersebut sudah seharusnya sebuah negara pantai melakukan upaya-upaya yang dibenarkan menurut UNCLOS untuk secepatnya melegitimasi hukum batas landas kontinennya kepada PBB melalui Komisi Batas landas Kontinen (CLCS).

Untuk mengajukan klaim atas landas kontinennya Indonesia perlu melakukan survey guna penetapan batas landas kontinen untuk itu diperlukan kerjasama dengan akademisi, yang memerlukan biaya besar tetapi potensi ekonomi yang akan dimiliki negara pantai jauh lebih besar. Sebelum menetapkan landas kontinen ekstensi sebaiknya Indonesia menyelesaikan terlebih dahulu perjanjian batas negaranya dengan negara-negara yang berbatasan dengan Indonesia di laut, baik dengan negara yang berdampingan atau berhadapan. Sebelum Indonesia melakukan delineasi batas terluar landas kontinennya dengan mengajukan pada CLCS.

\section{DAFTAR PUSTAKA \\ Buku:}

Arsana, I Made Andi, 2007, Batas Maritim Antarnegara, Sebuah Tinjauan Teknis dan Yuridis, Yogyakarta: Gadjah Mada Press.

Arsana, I Made Andi, Deliniasi Batas Landas Kontinen Ekstensi Indonesia: Status dan Permasalahannya, diakses dari http;//geologi.ugm.ac.id, 27 Maret 2008

Churchil, R.R., and Lowe, A.V., 1983, The Law of the Sea, Manchester University Press.

D. J. Starke, 1979, Pengantar Hukum Internasional, Jakarta: Sinar Grafika.

D. P. O'Connell, 1984, The International Law of the $\mathrm{Sea}$, Vol.I, Edited by Shearer, Clarendom Press.

Drujanah, Eka dan Tangguh Dewantara, 2002, Penetapan Batas Landas Kontinen Indonesia, Jurnal Surveying dan Geodesi, Vol XII. No. 3.

Jalal, Hasjim, 1979, Perjuangan Indonesia di Bidang Hukum Laut, Bandung: Binacipta.

Jawhari, Tantowi \& Iskandar Pranoto, Hukum Internasional Kontemporer, Refika Aditama.

Kalean, M.S., 2002, Pendidikan Kewarganegaraan untuk Perguruan Tinggi, Yogyakarta: Paradikma.

Kusumaatmadja, Moctar, 1978, Bunga Rampai Hukum Laut, Bandung: Binacipta. , 1983, Hukum Laut Internasional, Bandung: Binacipta. 2002, Konsep-Kosep Hukum dalam Pembangunan, Kumpulan Karya Tulis, Bandung: Alumni.

Mauna, Boer, 2003, Hukum Internasional: Pengertian 
Tuhulele, Upaya Hukum Indonesia Mengajukan Landas Kontinen Ekstensi ....

Peran dan Fungsi dalam Era Dinamika Global, Bandung:Alumni

Parthiana, I Wayan, 2003, Pengantar Hukum Internasional, Bandung: Mandar Maju.

Subagyo, P. Joko, 1985, Perkembangan Hukum Laut Internasional, Jakarta: Ghalia Indonesia.
Tsani, Moh. Burhan, 1990, Hukum dan Hubungan Internasional, Yogyakarta: Liberty.

\section{Peraturan Perundang-undangan:}

United Nations Convention Law of The Sea, 1958. United Nations Convention Law of The Sea, 1982. 